\title{
Clinical and therapeutic implications of melanoma genomics
}

\author{
Michael Shaughnessy ${ }^{1}$, Nikolai Klebanov ${ }^{1}$, Hensin Tsao, ${ }^{1,2}$ \\ 'Wellman Center for Photomedicine, Massachusetts General Hospital, Harvard Medical School, Boston, 02114, USA. \\ ${ }^{2}$ Department of Dermatology, Massachusetts General Hospital, Boston, 02114, USA.
}

Correspondence to: Dr. Hensin Tsao, Wellman Center for Photomedicine, Massachusetts General Hospital, Harvard Medical School, Boston, 02114, USA. E-mail: HTSAO@mgh.harvard.edu

How to cite this article: Shaughnessy M, Klebanov N, Tsao H. Clinical and therapeutic implications of melanoma genomics. J Trans/ Genet Genom 2018;2:14. https://doi.org/10.20517/jtgg.2018.25

Received: 30 Aug 2018 First Decision: 7 Sep 2018 Revised: 15 Sep 2018 Accepted: 17 Sep 2018 Published: 28 Sep 2018

Science Editor: David N. Cooper Copy Editor: Cui Yu Production Editor: Zhong-Yu Guo

\begin{abstract}
Melanoma represents just $1 \%$ of skin cancer but is responsible for the vast majority of skin cancer deaths. Given its implications for therapeutic advancement, the field of melanoma genomics has dramatically expanded in recent years. At one time classified mainly by anatomical location - non-acral cutaneous melanoma (NACM), acral cutaneous melanoma (ACM), mucosal melanoma (MuM), or uveal melanoma (UM) are now further sub-classified based on the mutated genes that drive their initiation, progression, and survival. BRAF gene mutations in NACM are the most frequently occurring and the best-studied, giving rise to the successful use of BRAF inhibitors in clinical practice for the last decade. This development has opened the door for many promising clinical trials and countless investigations into melanoma's genetic underpinnings. In this review, we offer an overview of melanoma genomics and discuss the most relevant somatic mutations such as BRAF, NRAS, and NF1 in NACM, KIT in ACM and MuM, and GNAQ, GNA11, and $B A P 7$ in UM. Particular emphasis is placed on the biochemical pathways driven by each mutation, their associated clinical manifestations, and their role as current and future therapeutic targets.
\end{abstract}

Keywords: Melanoma, cutaneous melanoma, genetics, genomics, BRAF, NRAS, NF1, skin cancer

\section{INTRODUCTION}

In 2018, there will be an estimated 91,270 new cases of melanoma and 9320 deaths attributable to melanoma ${ }^{[1]}$. Compared to the estimates from ten years prior in 2008 of 62,480 cases and 8420 deaths, it is clear that the incidence continues to dramatically rise while the number of deaths has stabilized ${ }^{[2]}$. This apparent improvement in survival is due, in part, to the discovery of novel therapeutic agents targeting specific melanoma genetic drivers, such as vemurafenib, dabrafenib, and trametinib in BRAF-mutant tumors ${ }^{[3,4]}$.

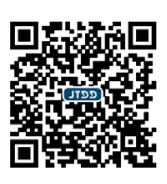


Given our growing understanding of the mutations driving melanoma progression, we now have multiple options for recurrent and metastatic tumors that were once considered untreatable. We are also better able to identify those patients who would benefit from earlier and more thorough cancer screening due to the discovery of hereditary forms of cancer and their associations with cancers of other organs ${ }^{[5]}$. Despite our expanding knowledge of melanoma's genetic landscape with over 40 culprit mutated genes identified to date, a relatively small number of clinically-relevant drugs have been developed ${ }^{[6]}$. This disparity is due to the remarkably intricate nature of cancer genetics, involving the complex interplay between driver and passenger mutations and variability in gene expression and gene-gene interactions. Considering the modest progress towards improving the prognosis of uveal melanoma, or in developing a universal melanoma chemotherapeutic agent, it is clear that much remains to be discovered.

We will focus largely on somatic driver mutations in melanoma. An extensive discussion of germline variants and their associated familial cancer syndromes is beyond the scope of this review.

\section{NON-ACRAL CUTANEOUS MELANOMA}

Non-acral cutaneous melanoma (NACM), comprised of the superficial spreading, nodular, lentigo maligna, and desmoplastic subtypes, is the most common type of melanoma, and thus the most well-studied and wellunderstood in terms of its genetic foundation. NACM predominantly affects sun-exposed surfaces of white individuals with fair skin, and its risk is highly associated with UV radiation exposure ${ }^{[7]}$. Superficial spreading melanoma is the most common form, representing $70 \%$ of all cases of melanoma, and is more likely to be associated with a prior nevus and a history of sporadic and intense UV exposure ${ }^{[8]}$. Nodular melanoma often presents as a darkly-pigmented or amelanotic nodule that is thicker than other subtypes at the time of diagnosis. Lentigo maligna melanoma primarily arises in chronically sun-damaged skin of older individuals. Finally, the desmoplastic subtype is marked by an amelanotic scar-like formation that is characterized histologically by spindled melanocytes and abundant stroma ${ }^{[9]}$. From a genomic standpoint, NACM is generally characterized as being made up of four major subclasses: BRAF, NRAS, NF1, and triple-wild type [Table 1].

\section{BRAF}

Mutations in BRAF are the most frequently occurring driver mutations in melanoma (60\% of all tumors) ${ }^{[36]}$. $B R A F$ encodes a serine/threonine protein kinase that regulates the mitogen-activated protein kinase (MAPK) pathway, which is involved in cell proliferation, differentiation, and survival. BRAF mutations have been implicated in several other malignancies, such as colorectal carcinoma, ovarian carcinoma, and various sarcomas $^{[36]}$. The V600E missense mutation, which results in a valine to glutamic acid substitution, is present in $80 \%$ of $B R A F$-mutated melanomas. This mutation significantly upregulates BRAF kinase activity thereby activating downstream MAPK signaling and driving cancer progression ${ }^{[36]}$.

BRAF-mutated melanomas are more often found in younger patients and in areas exposed to intermittent sunlight ${ }^{[10]}$, but the same V600E mutation is also present in $80 \%$ of benign nevi, suggesting that tumorigenesis requires additional co-mutations ${ }^{[11]}$.

BRAF-mutated melanomas were first successfully treated with the BRAF inhibitor vemurafenib in 2010, and now are treated with the gold standard combination of dabrafenib (BRAF inhibitor, BRAFi) and trametinib (MEK inhibitor, MEKi) ${ }^{[3,12,37]}$. Trametinib targets downstream MEK1 and MEK2. The combination of BRAFi+MEKi suppresses MAPK signaling at two points which enhances efficacy ${ }^{[38]}$. Several resistance mechanisms have developed in response to BRAF inhibitors including novel splice variants in BRAF, BRAF gene amplification, activation of receptor tyrosine kinases and other kinases, or through an immune-mediated mechanism ${ }^{[23]}$. Clinical trials are currently investigating treatments for these resistance patterns. One promising option may be a combination of the current standard of dabrafenib/trametinib with immunomodula- 
Table 1. Summary of the major melanoma driver mutations

\begin{tabular}{|c|c|c|c|c|}
\hline Melanoma Subtype & $\begin{array}{l}\text { Mutated gene } \\
\text { (\% of subtype) }\end{array}$ & Clinical manifestations & $\begin{array}{l}\text { Relative prognostic } \\
\text { implications }\end{array}$ & Treatment options \\
\hline \multirow[t]{4}{*}{ Non-acral cutaneous } & $\operatorname{BRAF}(60)^{[6]}$ & $\begin{array}{l}\text { Younger patients, intermittent } \\
\text { sunlight, presence in benign } \\
\text { nevi }{ }^{[10,1]}\end{array}$ & neutral & $\begin{array}{l}\text { Gold standard: combination } \\
\text { dabrafenib and trametinib or } \\
\text { immune checkpoint inhibitors. } \\
\text { Clinical trials: dabrafenib and } \\
\text { trametinib with PD-1 inhibitors. } \\
\text { Several others }{ }^{[12,13]}\end{array}$ \\
\hline & $\operatorname{NRAS}(28)^{[6]}$ & $\begin{array}{l}\text { Older patients, non-sun-damaged } \\
\text { skin, presence in benign nevi }{ }^{[10,14,15]}\end{array}$ & Unfavorable ${ }^{[16]}$ & $\begin{array}{l}\text { Clinical trials: MEK1/2 } \\
\text { inhibitors, CDK4/6 } \\
\text { inhibitors }^{[17,18]}\end{array}$ \\
\hline & $N F 1(14)^{[6]}$ & $\begin{array}{l}\text { Older/male patients, sun-exposed } \\
\text { skin }^{[19]}\end{array}$ & Unfavorable $^{[20]}$ & $\begin{array}{l}\text { No ongoing trials specifically } \\
\text { targeting this gene mutation }\end{array}$ \\
\hline & Triple wild-type $(15)^{[6]}$ & Male patients ${ }^{[20]}$ & Unfavorable & $\begin{array}{l}\text { No ongoing trials or targeted } \\
\text { therapy options }\end{array}$ \\
\hline \multirow[t]{3}{*}{$\begin{array}{l}\text { Mucosal/ Acral } \\
\text { cutaneous }\end{array}$} & $\mathrm{KIT}(39 \mathrm{MuM} / 36 \mathrm{ACM})^{[21]}$ & Chronically sun-damaged skin ${ }^{[21]}$ & Unfavorable $^{[22]}$ & $\begin{array}{l}\text { Limited results with } \\
\text { kinase inhibitors (imatinib, } \\
\text { dasatinib, sorafenib, and } \\
\text { nilotinib). Additional trials: } \\
\text { kinase inhibitors with } \\
\text { immunotherapy }^{[23]}\end{array}$ \\
\hline & PDGFRA (4 MuM/7 ACM) $)^{[24]}$ & Non-sun-damaged skin ${ }^{[24]}$ & Neutral & $\begin{array}{l}\text { Preliminary results with } \\
\text { imatinib and crenolanib }{ }^{[25]}\end{array}$ \\
\hline & Cyclin D1 (45 ACM) ${ }^{[26]}$ & $\begin{array}{l}\text { Sun-damaged skin, resistance to } \\
\text { BRAFi }^{[26]}\end{array}$ & Neutral ${ }^{[27,28]}$ & $\begin{array}{l}\text { Clinical trials: CDK inhibitor } \\
\text { P276-00 }\end{array}$ \\
\hline \multirow[t]{4}{*}{ Uveal } & GNAQ/GNA11 (99) ${ }^{[30]}$ & Presence in benign nevi $i^{[31]}$ & Neutral $^{[30,32]}$ & $\begin{array}{l}\text { Clinical trials: solumetinib, } \\
\text { protein kinase } C \text { inhibitors }\end{array}$ \\
\hline & $\operatorname{BAP} 1(45)^{[30]}$ & $\begin{array}{l}\text { BAP1 cancer syndrome, } \\
\text { associated with other } \\
\text { malignancies }^{[34]}\end{array}$ & Unfavorable $^{[34]}$ & $\begin{array}{l}\text { Clinical trials: Niraparib (PARP } \\
\text { inhibitor) }^{[35]}\end{array}$ \\
\hline & $\operatorname{EIF1AX}(14)^{[30]}$ & None reported & Favorable $\mathrm{e}^{[34]}$ & No ongoing trials \\
\hline & SF3B1 $(22)^{[30]}$ & $\begin{array}{l}\text { Younger patients, associated with } \\
\text { late metastasis }{ }^{[34]}\end{array}$ & Unfavorable $^{[34]}$ & \\
\hline
\end{tabular}

MuM: mucosal melanoma; ACM: acral cutaneous melanoma; CDK: cyclin-dependent kinase

tory agents such as ipilimumab and nivolumab ${ }^{[13]}$.

\section{NRAS}

NRAS mutations, present in $1 / 3$ of NACMs, are the second most common driver mutation in melanoma ${ }^{[6]}$. The RAS family is a group of G-regulatory proteins that regulate cell growth and malignant transformation by activating both the MAPK pathway (as in BRAF-mutant melanomas) as well as the phosphoinositide 3-kinase (PI3K) pathway, an essential cell signaling pathway that promotes growth and survival independent of MAPK $^{[39]}$ [Figure 1]. NRAS, in particular, is mutated in $28 \%$ of RAS-mutant tumors, compared to HRAS in $1 \%$ and KRAS in $1 \%{ }^{[6]}$. NRAS Q61 is an activating missense mutation that renders the NRAS protein constitutively guanosine triphosphate (GTP)-bound and active, thus affecting a large number of downstream signaling molecules involved in cell cycle dysregulation, survival, and proliferation, such as the aforementioned PI3K and RAF kinases ${ }^{[40]}$.

NRAS-mutant tumors typically occur in non-sun-damaged skin in older patients but are also known to affect acral and mucosal sites. They have increased thickness, higher mitotic rates, and lower incidence of ulceration than their counterparts ${ }^{[10,14]}$. They also exhibit increased aggressiveness and poor survival ${ }^{[16]}$. Like $B R A F$ variants, NRAS mutations are commonly found in congenital nevi, again suggesting that NRAS variants alone are insufficient for tumorigenesis ${ }^{[15]}$. Despite activating the same MAPK pathway as BRAF mutations, NRAS variants are very rarely found within BRAF-mutated tumors, which has obvious implications for treatment development ${ }^{[41]}$. 


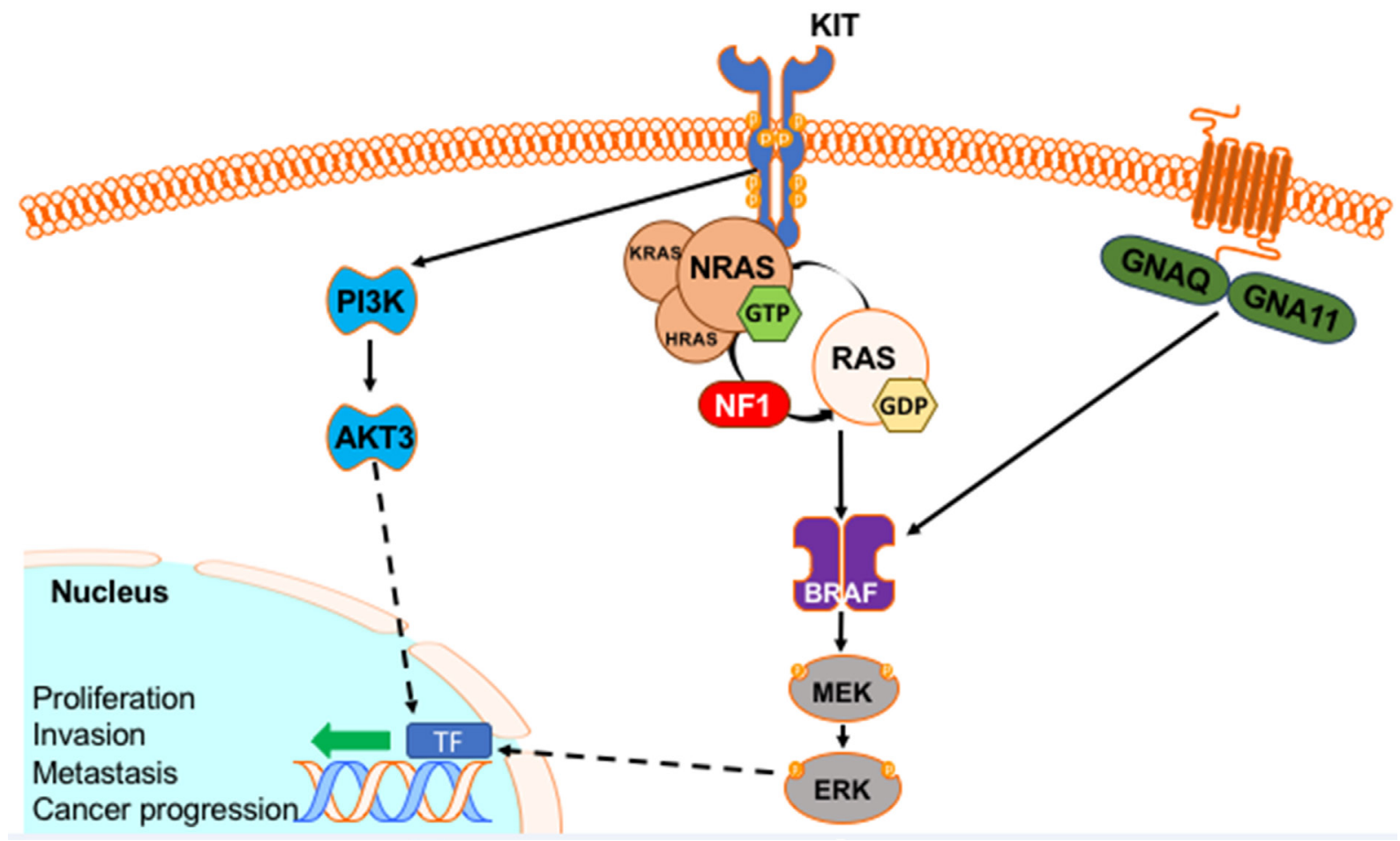

Figure 1. The interactions between the RAS/RAF/MEK/ERK, PI3K/AKT3/mTOR, KIT, and GNAQ/GNA11 pathways

There is a lack of targeted treatment options for NRAS-variant tumors, with only a few clinical trials and no approved drugs to date. Binimetinib, a MEK1/2 inhibitor that works downstream of the MAPK pathway, has demonstrated improvement over the traditional chemotherapeutic agent dacarbazine in a recent clinical tri$\mathrm{al}^{[17]}$. Several other options are currently being explored, most notably the combined use of MEK and cyclindependent kinase $4(\mathrm{CDK} 4 / 6)$ inhibitors $^{[18]}$.

\section{NF1}

NF1 is a tumor suppressor gene that encodes the protein neurofibromin 1, and is the third most common NACM driver, found in about $14 \%$ of tumors ${ }^{[1,42]}$. The GTPase-activating protein-related domain of NF1 negatively regulates RAS through conversion of activated RAS-GTP to inactive RAS-guanosine diphosphate. This results in constitutive activation of both the MAPK and PI3K pathways, driving tumorigenesis through the same signaling pathway as in BRAF and NRAS-variant tumors [Figure 1]. Despite this shared pathway, tumors with putative loss-of-function mutations in the NF1 gene generally lack the BRAF (V600E) mutation, and in fact, NF1 mutations have been proposed as a source of resistance to BRAF inhibitors ${ }^{[43]}$.

NF1-mutated tumors are clinically aggressive and have poor survival with very limited treatment options ${ }^{[20]}$. They tend to occur in sun-exposed skin in older male patients ${ }^{[19]}$, and are also associated with desmoplastic tumors, occurring more often in desmoplastic melanoma than any other NACM subtype ${ }^{[44,45]}$.

\section{Triple-wild type}

Triple-wild type NACM lacks any of the aforementioned mutations in BRAF, NRAS, or NF1 [Figure 2]. It is a rare, heterogeneous group of cancers, with a predisposition for males between the ages of $60-70^{[20]}$. Interestingly, it often harbors mutations in what are normally considered uveal melanoma drivers (discussed below), such as GNA11, GNAQ, SF3B1, and KIT mutations ${ }^{[6,20,46]}$. Given the lack of a consistently present driver mutation, triple-wild type NACM currently offers little promise for possible chemotherapy targets. 


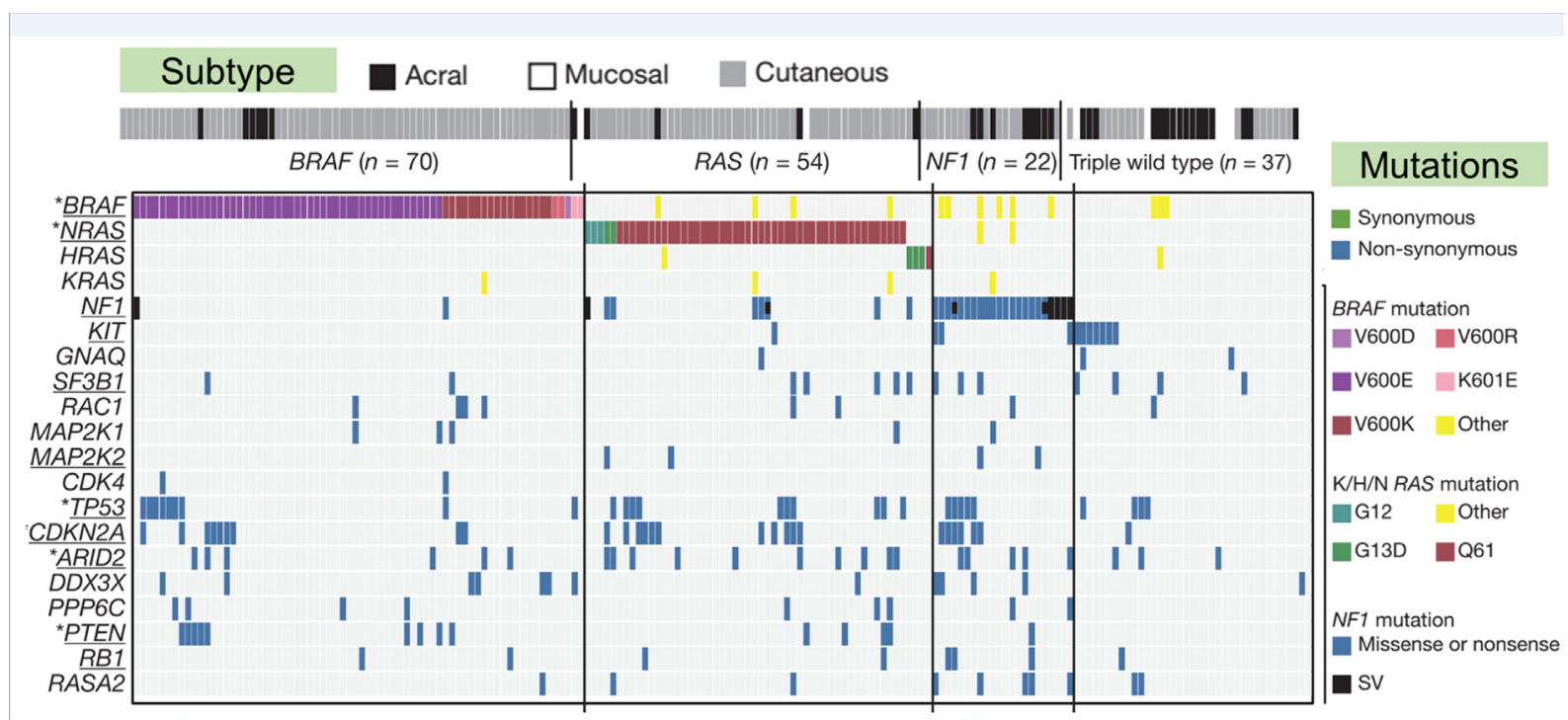

Figure 2. Selected driver mutations in melanoma broken down by non-acral cutaneous melanoma genomic subclass (BRAF, RAS, NF1, and triple-wild type) and melanoma subtype (acral, mucosal, cutaneous). Adapted with permission from Hayward et al. ${ }^{[46]}$

\section{Other mutations in NACM}

Several additional mutations are crucial in NACM development, progression, and survival. microphthalmiaassociated transcription factor (MITF) is a transcription factor that is required for early melanocyte development. While there are no activating mutations in MITF as in BRAF, about $10 \%$ of tumors exhibit amplification of the MITF locus ${ }^{[47,48]}$. It is associated with a decreased 5-year survival and a specific MITF variant (p.E318K) is also rarely seen as the product of a germline mutation predisposing patients to both melanoma and renal cell carcinoma ${ }^{[5,32]}$. Mutations in phosphatase and tensin homolog (PTEN), a tumor suppressor and key regulator of the PI3K pathway, are found in about $14 \%$ of melanomas ${ }^{[4,50]}$. Germline PTEN mutations are associated with Cowden syndrome in adults and Bannayan-Riley-Ruvalcaba syndrome in children and impart an increased risk for breast, thyroid, endometrial, kidney, and colorectal cancer in addition to melanoma ${ }^{[5]}$. Telomerase reverse transcriptase (TERT) encodes the catalytic subunit of the holoenzyme telomerase that is essential for sustaining telomere length and chromosomal stability, enabling cells to overcome replication-induced senescence, while allowing for additional mutations to accrue ${ }^{[51]}$. Amplification of the TERT locus along with TERT promoter mutations are quite common in melanoma ${ }^{[6]}$. TERT promoter variants recruit the GABP transcription factor and are present in $90 \%$ of aggressive malignancies ${ }^{[52]}$. Cyclindependent kinase inhibitor $2 \mathrm{~A}(\mathrm{CDKN} 2 \mathrm{~A})$ deletions and mutations along with cyclin-dependent kinase 4 (CDK4) amplifications and activating mutations disrupt G1-S transition in the cell cycle and lead to melanoma tumorigenesis ${ }^{[6,46]}$. Mutations in both genes have been implicated in hereditary melanoma, an autosomal dominant group of disorders characterized by patients with hundreds of dysplastic nevi and an increased risk for melanoma and other malignancies ${ }^{[5]}$.

\section{MUCOSAL MELANOMA AND ACRAL CUTANEOUS MELANOMA}

Perhaps as they both arise in sun-protected skin areas, acral cutaneous melanoma (ACM) and mucosal melanoma $(\mathrm{MuM})$ are more genetically similar to each other than to any of the other subtypes. Both account for higher percentages of melanoma among Black, Asian, and Hispanic populations, which reflects the lower rates of UV-related NACMs among these populations ${ }^{[6,53]}$. ACM represents $2 \%$ of primary melanomas ${ }^{[54]}$. It is an aggressive tumor that is associated with delayed diagnosis and poor prognosis ${ }^{[5]}$. MuM represents $1.3 \%$ of primary melanomas and is similarly associated with an advanced stage at diagnosis and a poor prognosis ${ }^{[56]}$. ACMs less commonly contain mutations in BRAF, NRAS, PTEN, TP53, and MAP2 $2_{2}^{[46,57]}$, while MuMs often harbor GNAQ and $S F 3 B 1$ gene mutations that are typically considered more characteristic of uveal 
melanoma ${ }^{[58,59]}$. A few of their most frequently recognized mutations are in the KIT, PDGFRA, and Cyclin D1 genes [Table 1].

\section{KIT (MuM and ACM)}

KIT mutations are present in just 3\% of all melanomas but are found in as many as 39\% of MuM and 36\% of ACM, making them the most common variant in both of these subtypes ${ }^{[2]}$. Additionally, it is the most commonly identified mutation in chronically sun-damaged skin at $28 \%{ }^{[2]}$. KIT encodes a type III transmembrane receptor tyrosine kinase that is vital for normal melanocyte development, as it is the receptor for stem cell factor (SCF). Upon binding SCF, KIT dimerizes and subsequently activates signaling pathways, including the MAPK/ERK and the PI3K/AKT/mTOR survival pathways [Figure 1]. Activating KIT mutations simulate this very same SCF ligand binding, thus activating pathways that influence cancer cell growth, proliferation, invasion, metastasis, and apoptosis evasion ${ }^{[60]}$. In melanoma, KIT mutations correlate with increased disease invasion and metastasis, highlighting its tumor suppressive function ${ }^{[22]}$. They are mutually exclusive with mutations in BRAF and NRAS, but still induce the same MAPK and PI3K pathways that are crucial to the tumorigenesis of several other melanoma subtypes.

Clinical trials have focused on the use of various kinase inhibitors, such as imatinib, dasatinib, sorafenib, and nilotinib, all with limited results in the attempted treatment of KIT-mutated tumors ${ }^{[23]}$.

\section{PDGFRA (MUM and ACM)}

A cell surface type III receptor tyrosine kinase, PDGFRA normally binds to platelet-derived growth factors and leads to the activation of cell signaling pathways essential for growth and differentiation. Mutations have also been implicated in the dysregulation of survival and tumor progression. Mutant PDGFRA is present in around $7 \%$ of ACM and $4 \%$ of MuM. PDGFRA mutations are mutually exclusive with KIT mutations and occur almost entirely in skin without chronic sun-damage ${ }^{[24]}$.

\section{CCND1 (ACM)}

CCND1 encodes the major cell cycle control protein cyclin D1. Cyclin D1 effectively controls cell proliferation through binding and stimulating CDK4/6, resulting in the phosphorylation of the retinoblastoma protein and subsequent cell cycle entry ${ }^{[6]}$. Amplification of the CCND1 gene is present in approximately $45 \%$ of $\mathrm{ACMs}^{[26]}$, and it is considered an ACM driver. However, the gene is also amplified in 6\% of NACMs, particularly in chronically sun-damaged $\operatorname{skin}^{[26]}$. CCND1 variants have even been found to incur resistance to BRAF inhibitors in $\mathrm{NACM}^{[61]}$.

\section{UVEAL MELANOMA}

Uveal melanoma (UM) arises from melanocytes of the uveal tract of the eye, and it is both the most common primary intraocular malignancy and the most common of the non-cutaneous melanomas (comprising $80 \%$ of these tumors ${ }^{[34,62]}$. UM has a poor prognosis, with nearly half of affected patients developing metastatic disease with an expected survival ranging from months to a year. The rarity of the disease limits patient availability for clinical trials and currently no effective systemic therapy exists ${ }^{[63]}$. Like cutaneous forms of melanoma, UM occurs primarily in white patients, particularly in those with light skin and light eyes, highlighting the possible significance of UV radiation in its development or the inherent susceptibility of melanocytes from these vulnerable populations ${ }^{[63,64]}$. The genetic landscape of UM is distinct from other melanomas, as evidenced by observations that UM rarely exhibits BRAF or NRAS mutations, which are characteristically present at all other melanoma sites, but rather is defined by GNAQ, GNA11, BAP1, EIF1AX, and $S F 3 B 1$ mutations [Table 1].

\section{GNAQ and GNA11}

Up to $99 \%$ of UM harbor GNAQ or GNA11 gene mutations ${ }^{[30]}$. GNAQ mutations alone have been found in 
$33 \%$ of uveal and $1.4 \%$ of cutaneous melanoma, and variants in GNA11 have been identified in $39 \%$ of uveal and $1.3 \%$ of cutaneous ${ }^{[31]}$. They are the most common UM driver mutations, and they were among the first to be described. The proteins these two genes encode are close relatives of the large GTPases in the G alpha subunit $\left(G \alpha_{q}\right)$ family, which are subunits of heterotrimeric $G$ proteins operating downstream of $G$ proteincoupled receptors (GPCRs) ${ }^{[65]}$. GNAQ and GNA11 encode the $G \alpha_{q}$ and alpha subunit 11 (Go11) respectively $^{[6]]}$. Both proteins mediate signaling between GPCRs and downstream effectors. Recurrent activating GNAQ (p.Q209) and GNA11 (p.Q209) mutations converge on the MAPK/ERK pathway and serve to constitutively upregulate the MAP kinase pathway, similarly to BRAF and NRAS activation in cutaneous melanoma $^{[59,6]]}$ [Figure 1]. GNAQ and GNA11 gene mutations display mutual exclusivity and are very rarely found to co-occur in the same tumor. Mutations in these genes are also present in benign uveal nevi and dermal melanocytic tumors and are considered an early event in uveal melanoma development and progression.

Despite GNA11 mutations displaying a stronger association with metastasis than those of GNAQ, neither mutation reveals any correlation with prognosis ${ }^{[30,32]}$. There have been very few promising trials to date. However, some moderate effects have been demonstrated with the MEK inhibitor, selumetinib, and recent studies are currently investigating protein kinase $\mathrm{C}$ as a potential target ${ }^{[33]}$.

\section{BAP1}

BRCA1-associated protein 1, or $B A P 1$, is a tumor suppressor gene that is lost due to the occurrence of monosomy 3 in $45 \%$ of $\mathrm{UM}^{[30]}$. The protein product of $B A P 1$ is a deubiquitinating hydrolase. BAP1 loss results in severe dysregulation of cell cycle regulation, DNA repair, and gene expression in multiple genomic regions $^{[5,68]}$.

Tumors with $B A P 1$ alterations or loss are potentially more aggressive with a poor prognosis. They are often found in older patients and are associated with as many as $80 \%$ of metastatic $\mathrm{UMs}^{[34]}$. Germline BAP1 mutations are found in BAP1 cancer syndrome, which predisposes patients to UM along with renal carcinoma, mesothelioma, and several other tumors. However, they are detected far more frequently as somatic variants ${ }^{[69]}$. Patients with BAP1 cancer syndrome are often recommended to pursue more frequent and thorough cancer screening along with genetic counseling. Unfortunately, few options remain for patients with BAP1 mutations once their UM becomes metastatic. Unlike oncogenes that can be targeted with any number of small molecule inhibitors, the nature of $B A P 1$ as a loss-of-function tumor suppressor gene has posed a challenge for the development of a targeted therapy.

\section{EIF1AX and SF3B1}

EIF1AX and $S F 3 B 1$ mutations are less common among UM, found in $14 \%$ and $22 \%$ of samples, respectively ${ }^{[30]}$. The two proteins encoded by these genes are responsible for the nuclear processes of translation initiation and pre-mRNA splicing, respectively. Mutations in EIF1AX and $S F 3 B 1$ are nearly mutually exclusive with each other as well as with $B A P 1$ variants. EIF1AX mutations are associated with a favorable prognosis, while $S F 3 B 1$ mutations are found in younger patients and are associated with the development of late metastasis ${ }^{[34]}$.

\section{MELANOMA GENOMICS}

\section{Mutational Burden}

Apart from differences in the underlying driver mutations, melanoma subtypes reveal variations in other key genomic attributes. For example, NACM has one of the highest tumor mutational burdens (TMB) among all human malignancies with around 10-50 mutations per megabase; in contrast, UM has one of the lowest and ACM/MuM only have around 2-3 mutations per megabase ${ }^{[20,70-72]}$. High TMB was initially established as a marker of clinical benefit in NACM after immunotherapy with CTLA-4 blockade by ipilimumab, and a high TMB in TCGA metastatic melanoma cohort was associated with improved survival ${ }^{[7,77]}$. One hypothesis is that increased TMB causes higher rates of neoantigen presentation and increased tumor im- 
mune surveillance ${ }^{[75]}$. Even among cutaneous melanoma genomic subgroups, mutational load shows minor variations, with $N F 1$-subtype tumors displaying a higher TMB compared to BRAF, NRAS, and triple wildtype tumors ${ }^{[20]}$.

\section{Mutational Signatures}

Different environmental and molecular forces, such as exposure to carcinogens (smoking, UV light, etc.), result in distinct mutational processes leaving unique DNA "footprints," or combinations of mutation types termed "signatures." Over twenty mutational signatures have been described to date ${ }^{[76]}$. Cutaneous melanoma mutational spectra are most highly enriched in Signature 7, which is associated with ultraviolet radiation and a predominance of cytosine to thymine transitions. These $\mathrm{C}$ to $\mathrm{T}$ transitions are driven predominantly by photodimer creation through direct UV exposure or by indirect DNA damage from UV radiation ${ }^{[2,77]}$. The mutational signatures in NACM are entirely distinct from the non-ultraviolet radiation associated signatures found in acral and mucosal melanomas. Of the nine signatures characteristic of ACM and MuM, signature 1 (associated with increased patient age) and signature 5 (unknown etiology) are the most common, which is fitting given these tumors arise in infrequently sun-exposed areas. These observations reflect how differing levels of UV carcinogen exposure result in profound genomic delineation of these melanoma subtypes.

\section{Structural variants}

Structural variants include copy number variants (CNVs), amplifications, duplications, deletions, and foldback inversions involving DNA regions of $1 \mathrm{~kb}$ or longer ${ }^{[78,79]}$, and provides another dimension to tumor genetic diversity. Candidate CNV discovery and genotyping has already identified important genetic links to several complex disorders such as psoriasis and Crohn's disease ${ }^{[79]}$.

The four genomic subtypes of NACM exhibit preferential gene amplifications. BRAF and MITF gene amplifications are more characteristic of the BRAF-mutant subtype, while the triple wild-type subtype frequently reveals KIT oncogene 4 p12 focal amplification. The triple wild-type subtype also has significantly more copynumber segments overall than BRAF, NRAS, and NF1 types. ACM and MuM both exhibit a higher frequency of chromosomal aberrations and CNVs compared to $\mathrm{NACM}^{[20,80]}$. ACM and MuM also are both more likely to show higher copy number alterations in CDK4 and lower copy number alterations in $C D K N 2 A$ and $P T E N^{[80]}$. ACM reveal copy number gains in TERT in approximately one-fourth of cases ${ }^{[8]}$. KIT copy number gains or amplifications are also common in both ACM and MuM, observed in approximately one-fourth of cases of each tumor ${ }^{[82]}$.

\section{Gene expression profiling}

The broad analysis of mRNA levels across thousands of known genes has significantly contributed to our understanding of the cellular and molecular mechanisms underlying melanoma development ${ }^{[83]}$. An early gene expression profiling (GEP) analysis of metastatic melanoma revealed 4 molecular subclasses (high immune, pigmentation, proliferative and normal-like) with the proliferative subclass having the worst outcome $e^{[84]}$. This 4 -class categorization and prognostic association have since been validated in primary melanomas ${ }^{[85]}$. In TCGA melanoma specimens, GEP revealed 3 molecular subclasses of melanoma (keratin, MITF-low, and immune gene expression classes $)^{[6]}$. Some metastatic melanomas show keratin class expression patterns with increased expression of keratins, kallikreins, and other genes of the epidermis. The MITF-low subclass, in contrast, is characterized by low expression of epithelial expression and pigmentation genes, as well as genes responsible for immunomodulation, adhesion, and migration. The immune class is characterized by a high expression of immune signaling molecules, checkpoint proteins, and cytokines. This subset of melanoma patients presents with tumors containing an inflammatory infiltrate of T-lymphocytes and cytokines. Patients who develop tumors with the molecular expression pattern of the immune class show improved survival compared to keratin and MITF-low subclasses ${ }^{[6,86]}$. Given the expanding armamentarium and widespread use of immunotherapy, 
melanomas with immune and non-immune gene expression signatures may be expected to show different responses to such immunotherapeutic agents.

UMs separate into two distinct classes upon $\mathrm{GEP}^{[87]}$. Class 1 uveal melanomas exhibit low-grade behavior, a low metastatic risk, and overall good prognosis ${ }^{[88]}$. In contrast, class 2 tumors show high-grade behavior and worse prognosis overall, with a $72 \% 5$-year metastatic risk. Class 2 tumors are associated with loss-of-function BAP1 mutations, which impart additional loss of tumor suppressive function and increased aggressive tumor behavior. The advancements in our understanding of GEP of UM has resulted in the development of a commercially available 15-gene FDA-approved qPCR-based assay to risk stratify patients according to class 1 and class 2 uveal melanoma tumor status ${ }^{[89]}$. The role of prognostic GEP for NACM is currently being explored, and further validation may help establish new guidelines for clinical risk-stratification with GEP ${ }^{[90,91]}$.

\section{Pan-cancer analyses}

Thanks to the collaborative efforts and remarkably impactful initial results of TCGA, dozens of further studies have been published using the entire dataset of 33 cancer types and 1,1000 tumor samples that TCGA initially investigated $^{[92]}$. These pan-cancer analyses, which utilize data across cancer types, are unique in that they contextualize melanoma among a comprehensive cancer panel. They have confirmed previously known findings about melanoma and are unveiling novel connections between genomics, immunology, molecular biology, and clinical outcomes in all 33 cancer types ${ }^{[93-96]}$. In their recent analysis of TCGA data, Bailey et al. ${ }^{[93]}$ confirmed that UM and NACM have diametrically-opposed genetic features, even when considered amongst the larger cohort of tumor samples. By demonstrating that NACM harbors one of the largest amounts of overall mutations and UV signature mutations in the cohort, and UM one of the lowest, these results have helped to characterize the magnitude of the genetic differences among melanocytic tumors. In our pursuit of targeted treatments for uveal melanoma, perhaps we should focus elsewhere than simply on what is already known about cutaneous melanoma's molecular machinery. Pan-cancer analyses that evaluate cancer genomics as a whole, identifying shared features amongst cancer types, may be able to bridge the gap between UM's genomic foundations and its relatively grim prognosis.

\section{CONCLUSION}

Our current collective knowledge of melanoma's genetic landscape has already yielded significant clinical impact, dramatically altering the prognostic course for countless melanoma patients, and this knowledge will continue to expand in the coming years. Despite this progress, very few actionable discoveries have been made of targeted therapeutic strategies for the roughly half of patients whose melanomas are driven by mutations other than BRAF. Each melanoma subtype offers a unique set of therapeutic targets, only some of which have proven fruitful. New genes will continue to be identified, and in turn, chosen as possible therapeutic targets. Regardless, we will, unfortunately, continue to face a lack of universally-applicable treatments for metastatic melanoma. Melanoma genomics and the use of immune-mediated treatments provide one possible solution, but there remains much to be discovered.

\section{DECLARATIONS}

\section{Authors' contributions}

Design: Shaughnessy M

Literature research: Shaughnessy M

Manuscript writing, editing, revision: Shaughnessy M, Klebanov N, Tsao H

\section{Availability of data and materials}

Not applicable.

\section{Financial support and sponsorship}

This activity was supported in part by the U.S. NIH (K24 CA149202 to H.T.). 


\section{Conflicts of interest}

\section{All authors declared that there were no conflicts of interest.}

\section{Ethical approval and consent to participate}

Not applicable.

\section{Consent for publication}

Not applicable.

\section{Copyright}

(c) The Author(s) 2018.

\section{REFERENCES}

1 Siegel RL, Miller KD, Jemal A. Cancer statistics, 2018. CA Cancer J Clin 2018;68:7-30.

2. Jemal A, Siegel R, Ward E, Hao Y, Xu J, Murray T, Thun MJ. Cancer statistics, 2008. CA Cancer J Clin 2008;58:71-96.

3. Chapman PB, Hauschild A, Robert C, Haanen JB, Ascierto P, Larkin J, Dummer R, Garbe C, Testori A, Maio M, Hogg D, Lorigan P, Lebbe C, Jouary T, Schadendorf D, Ribas A, O’Day SJ, Sosman JA, Kirkwood JM, Eggermont AM, Dreno B, Nolop K, Li J, Nelson B, Hou J, Lee RJ, Flaherty KT, McArthur GA; BRIM-3 Study Group. Improved survival with vemurafenib in melanoma with BRAF V600E mutation. N Engl J Med 2011;364:2507-16.

4. Flaherty KT, Puzanov I, Kim KB, Ribas A, McArthur GA, Sosman JA, O’Dwyer PJ, Lee RJ, Grippo JF, Nolop K, Chapman PB. Inhibition of mutated, activated BRAF in metastatic melanoma. N Engl J Med 2010;363:809-19.

5. Ransohoff KJ, Jaju PD, Tang JY, Carbone M, Leachman S, Sarin KY. Familial skin cancer syndromes: increased melanoma risk. J Am Acad Dermatol 2016;74:423-34.

6. Cancer Genome Atlas Network. Genomic classification of cutaneous melanoma. Cell 2015;161:1681-96.

7. Schadendorf D, Fisher DE, Garbe C, Gershenwald JE, Grob JJ, Halpern A, Herlyn M, Marchetti MA, McArthur G, Ribas A, Roesch A, Hauschild A. Melanoma. Nat Rev Dis Primers 2015;1:15003.

8. Bailey EC, Sober AJ, Tsao H, Mihm Jr MC, Johnson Jr TM. Cutaneous melanoma. In: Fitzpatrick's dermatology in general medicine, 8e. New York: McGraw-Hill Global Education Holdings, LLC.; 2012.

9. Rabbie R, Adams DJ. Desmoplastic melanoma: C > Ts and NF- $\kappa$ B. Pigment Cell Melanoma Res 2015;29:120-1.

10. Johnson DB, Puzanov I. Treatment of NRAS-mutant melanoma. Curr Treat Options Oncol 2015;16:15.

11. Pollock PM, Harper UL, Hansen KS, Yudt LM, Stark M, Robbins CM, Moses TY, Hostetter G, Wagner U, Kakareka J, Salem G, Pohida T, Heenan P, Duray P, Kallioniemi O, Hayward NK, Trent JM, Meltzer PS. High frequency of BRAF mutations in nevi. Nat Genet 2003;33:1920 .

12. Flaherty KT, Infante JR, Daud A, Gonzalez R, Kefford RF, Sosman J, Hamid O, Schuchter L, Cebon J, Ibrahim N, Kudchadkar R, Burris HA 3rd, Falchook G, Algazi A, Lewis K, Long GV, Puzanov I, Lebowitz P, Singh A, Little S, Sun P, Allred A, Ouellet D, Kim KB, Patel K, Weber J. Combined BRAF and MEK inhibition in melanoma with BRAF V600 mutations. N Engl J Med 2012;367:1694-703.

13. Liu L, Mayes PA, Eastman S, Shi H, Yadavilli S, Zhang T, Yang J, Seestaller-Wehr L, Zhang SY, Hopson C, Tsvetkov L, Jing J, Zhang $\mathrm{S}$, Smothers J, Hoos A. The BRAF and MEK inhibitors dabrafenib and trametinib: effects on immune function and in combination with immunomodulatory antibodies targeting PD-1, PD-L1, and CTLA-4. Clin Cancer Res 2015; doi: 10.1158/1078-0432.CCR-14-2339.

14. Ellerhorst JA, Greene VR, Ekmekcioglu S, Warneke CL, Johnson MM, Cooke CP, Wang LE, Prieto VG, Gershenwald JE, Wei Q, Grimm EA. Clinical correlates of NRAS and BRAF mutations in primary human melanoma. Clin Cancer Res 2011;17:229-35.

15. Bauer J, Curtin JA, Pinkel D, Bastian BC. Congenital melanocytic nevi frequently harbor NRAS mutations but no BRAF mutations. J Invest Dermatol 2007; 127:179-82.

16. Manzano JL, Layos L, Bugés C, de Los Llanos Gil M, Vila L, Martínez-Balibrea E, Martínez-Cardús A. Resistant mechanisms to BRAF inhibitors in melanoma. Ann Transl Med 2016;4:237.

17. Ascierto PA, Schadendorf D, Berking C, Agarwala SS, van Herpen CM, Queirolo P, Blank CU, Hauschild A, Beck JT, St-Pierre A, Niazi F, Wandel S, Peters M, Zubel A, Dummer R. MEK162 for patients with advanced melanoma harbouring NRAS or Val600 BRAF mutations: a non-randomised, open-label phase 2 study. Lancet Oncol 2013;14:249-56.

18. Sosman JA, Kittaneh M, Lolkema MP, Postow M, Schwartz G, Franklin C, Matano A, Bhansali S, Parasuraman S, Kim K. A phase 1b/2 study of LEE011 in combination with binimetinib (MEK162) in patients with NRAS-mutant melanoma: early encouraging clinical activity. J Clin Oncol 2014;32:9009.

19. Krauthammer M, Kong Y, Bacchiocchi A, Evans P, Pornputtapong N, Wu C, McCusker JP, Ma S, Cheng E, Straub R, Serin M, Bosenberg M, Ariyan S, Narayan D, Sznol M, Kluger HM, Mane S, Schlessinger J, Lifton RP, Halaban R. Exome sequencing identifies recurrent mutations in NF1 and RASopathy genes in sun-exposed melanomas. Nat Genet 2015;47:996-1002.

20. Cirenajwis H, Lauss M, Ekedahl H, Törngren T, Kvist A, Saal LH, Olsson H, Staaf J, Carneiro A, Ingvar C, Harbst K, Hayward NK, Jönsson G. NF1-mutated melanoma tumors harbor distinct clinical and biological characteristics. Mol Oncol 2017;11:438-51.

21. Curtin JA, Busam K, Pinkel D, Bastian BC. Somatic activation of KIT in distinct subtypes of melanoma. J Clin Oncol 2006;24:4340-6. 
22. Natali PG, Nicotra MR, Winkler AB, Cavaliere R, Bigotti A, Ullrich A. Progression of human cutaneous melanoma is associated with loss of expression of c-kit proto-oncogene receptor. Int J Cancer 1992;52:197-201.

23. Reddy BY, Miller DM, Tsao H. Somatic driver mutations in melanoma. Cancer 2017;123:2104-17.

24. Merkel EA, Gerami P. Malignant melanoma of sun-protected sites: a review of clinical, histological, and molecular features. Lab Invest 2017;97:630-5.

25. Dai J, Kong Y, Si L, Chi Z, Cui C, Sheng X, Mao L, Li S, Lian B, Yang R, Liu S, Xu X, Guo J. Large-scale analysis of PDGFRA mutations in melanomas and evaluation of their sensitivity to tyrosine kinase inhibitors imatinib and crenolanib. Clin Cancer Res 2013;19:6935-42.

26. Sauter ER, Yeo UC, von Stemm A, Zhu W, Litwin S, Tichansky DS, Pistritto G, Nesbit M, Pinkel D, Herlyn M, Bastian BC. Cyclin D1 is a candidate oncogene in cutaneous melanoma. Cancer Res 2002;62:3200-6.

27. Flørenes VA, Faye RS, Maelandsmo GM, Nesland JM, Holm R. Levels of cyclin D1 and D3 in malignant melanoma: deregulated cyclin D3 expression is associated with poor clinical outcome in superficial melanoma. Clin Cancer Res 2000;6:3614-20.

28. Oba J, Nakahara T, Abe T, Hagihara A, Moroi Y, Furue M. Expression of c-Kit, p-ERK and cyclin D1 in malignant melanoma: an immunohistochemical study and analysis of prognostic value. J Dermatol Sci 2011;62:116-23.

29. US National Library of Medicine. Efficacy study of P276-00 in subjects of malignant melanoma positive for cyclin D1 expression (ENVER). Available from: https://clinicaltrials.gov/ct2/show/NCT00835419. [Last accessed on 19 Sept 2018]

30. Field MG, Durante MA, Anbunathan H, Cai LZ, Decatur CL, Bowcock AM, Kurtenbach S, Harbour JW. Punctuated evolution of canonical genomic aberrations in uveal melanoma. Nat Commun 2018;9:116.

31. Shoushtari AN, Carvajal RD. GNAQ and GNA11 mutations in uveal melanoma. Melanoma Res 2014;24:525-34.

32. Shtivelman E, Davies MQ, Hwu P, Yang J, Lotem M, Oren M, Flaherty KT, Fisher DE. Pathways and therapeutic targets in melanoma. Oncotarget 2014;5:1701-52.

33. Carvajal RD, Sosman JA, Quevedo JF, Milhem MM, Joshua AM, Kudchadkar RR, Linette GP, Gajewski TF, Lutzky J, Lawson DH, Lao CD, Flynn PJ, Albertini MR, Sato T, Lewis K, Doyle A, Ancell K, Panageas KS, Bluth M, Hedvat C, Erinjeri J, Ambrosini G, Marr B, Abramson DH, Dickson MA, Wolchok JD, Chapman PB, Schwartz GK. Effect of selumetinib vs chemotherapy on progression-free survival in uveal melanoma: a randomized clinical trial. JAMA 2014;311:2397-405.

34. Doherty RE, Alfawaz M, Francis J, Lijka-Jones B, Sisley K. Genetics of uveal melanoma. In: Scott JF, Gerstenblith MR, editors. Noncutaneous melanoma [Internet]. Brisbane (AU): Codon Publications; 2018. p. 19-36.

35. US National Library of Medicine. A trial of niraparib in BAP1 and other DNA damage response (DDR) deficient neoplasms (UF-STOETI-001). Available from: https://clinicaltrials.gov/ct2/show/NCT03207347. [Last accessed on 19 Sept 2018]

36. Davies H, Bignell GR, Cox C, Stephens P, Edkins S, Clegg S, Teague J, Woffendin H, Garnett MJ, Bottomley W, Davis N, Dicks E, Ewing R, Floyd Y, Gray K, Hall S, Hawes R, Hughes J, Kosmidou V, Menzies A, Mould C, Parker A, Stevens C, Watt S, Hooper S, Wilson R, Jayatilake H, Gusterson BA, Cooper C, Shipley J, Hargrave D, Pritchard-Jones K, Maitland N, Chenevix-Trench G, Riggins GJ, Bigner DD, Palmieri G, Cossu A, Flanagan A, Nicholson A, Ho JW, Leung SY, Yuen ST, Weber BL, Seigler HF, Darrow TL, Paterson H, Marais R, Marshall CJ, Wooster R, Stratton MR, Futreal PA. Mutations of the BRAF gene in human cancer. Nature 2002;417:949-54.

37. Sosman JA, Kim KB, Schuchter L, Gonzalez R, Pavlick AC, Weber JS, McArthur GA, Hutson TE, Moschos SJ, Flaherty KT, Hersey P, Kefford R, Lawrence D, Puzanov I, Lewis KD, Amaravadi RK, Chmielowski B, Lawrence HJ, Shyr Y, Ye F, Li J, Nolop KB, Lee RJ, Joe AK, Ribas A. Survival in BRAF V600-mutant advanced melanoma treated with vemurafenib. N Engl J Med 2012;366:707-14.

38. Wagle N, Emery C, Berger MF, Davis MJ, Sawyer A, Pochanard P, Kehoe SM, Johannessen CM, Macconaill LE, Hahn WC, Meyerson M, Garraway LA. Dissecting therapeutic resistance to RAF inhibition in melanoma by tumor genomic profiling. J Clin Oncol 2011;29:3085-96.

39. Hawryluk EB, Tsao H. Melanoma: clinical features and genomic insights. Cold Spring Harb Perspect Med 2014;4:a015388.

40. Muñoz-Couselo E, Adelantado EZ, Ortiz C, García JS, Perez-Garcia J. NRAS-mutant melanoma: current challenges and future prospect. Onco Targets Ther 2017;10:3941-7.

41. Raaijmakers MI, Widmer DS, Narechania A, Eichhoff O, Freiberger SN, Wenzina J, Cheng PF, Mihic-Probst D, Desalle R, Dummer R, Levesque MP. Co-existence of BRAF and NRAS driver mutations in the same melanoma cells results in heterogeneity of targeted therapy resistance. Oncotarget 2016;7:77163-74.

42. Ars E, Kruyer H, Morell M, Pros E, Serra E, Ravella A, Estivill X, Lázaro C. Recurrent mutations in the NF1 gene are common among neurofibromatosis type 1 patients. J Med Genet 2003;40:e82.

43. Whittaker SR, Theurillat JP, Van Allen E, Wagle N, Hsiao J, Cowley GS, Schadendorf D, Root DE, Garraway LA. A genome-scale RNA interference screen implicates NF1 loss in resistance to RAF inhibition. Cancer discov 2013;3:350-62.

44. Shain AH, Garrido M, Botton T, Talevich E, Yeh I, Sanborn JZ, Chung J, Wang NJ, Kakavand H, Mann GJ, Thompson JF, Wiesner T, Roy R, Olshen AB, Gagnon A, Gray JW6, Huh N, Hur JS, Busam KJ, Scolyer RA, Cho RJ, Murali R, Bastian BC. Exome sequencing of desmoplastic melanoma identifies recurrent NFKBIE promoter mutations and diverse activating mutations in the MAPK pathway. Nat Genet 2015;47:1194-9.

45. Kadokura A, Frydenlund N, Leone DA, Yang S, Hoang MP, Deng A, Hernandez-Perez M, Biswas A, Singh R, Yaar R, Mahalingam M. Neurofibromin protein loss in desmoplastic melanoma subtypes: implicating NF1 allelic loss as a distinct genetic driver? Hum Pathol 2016;53:82-90.

46. Hayward NK, Wilmott JS, Waddell N, Johansson PA, Field MA, Nones K, Patch AM, Kakavand H, Alexandrov LB, Burke H, Jakrot V, Kazakoff S, Holmes O, Leonard C, Sabarinathan R, Mularoni L, Wood S, Xu Q, Waddell N, Tembe V, Pupo GM, De Paoli-Iseppi R, Vilain RE, Shang P, Lau LMS, Dagg RA, Schramm SJ, Pritchard A, Dutton-Regester K, Newell F, Fitzgerald A, Shang CA, Grimmond SM, Pickett HA, Yang JY, Stretch JR, Behren A, Kefford RF, Hersey P, Long GV, Cebon J, Shackleton M, Spillane AJ, Saw RPM, López-Bigas N, Pearson JV, Thompson JF, Scolyer RA, Mann GJ. Whole-genome landscapes of major melanoma subtypes. Nature 2017;545:175-80.

47. Wellbrock C, Arozarena I. Microphthalmia-associated transcription factor in melanoma development and MAP-kinase pathway targeted therapy. Pigment Cell Melanoma Res 2015;28:390-406.

48. Garraway LA, Widlund HR, Rubin MA, Getz G, Berger AJ, Ramaswamy S, Beroukhim R, Milner DA, Granter SR, Du J, Lee C, Wagner 
SN, Li C, Golub TR, Rimm DL, Meyerson ML, Fisher DE, Sellers WR. Integrative genomic analyses identify MITF as a lineage survival oncogene amplified in malignant melanoma. Nature 2005;436:117-22.

49. Birck A, Ahrenkiel V, Zeuthen J, Hou-Jensen K, Guldberg P. Mutation and allelic loss of the PTEN/MMAC1 gene in primary and metastatic melanoma biopsies. J Invest Dermatol 2000;114:277-80.

50. Shain AH, Yeh I, Kovalyshyn I, Sriharan A, Talevich E, Gagnon A, Dummer R, North J, Pincus L, Ruben B, Rickaby W, D'Arrigo C, Robson A, Bastian BC. The genetic evolution of melanoma from precursor lesions. N Engl J Med 2015;373:1926-36.

51. Chiba K, Lorbeer FK, Shain AH, McSwiggen DT, Schruf E, Oh A, Ryu J, Darzacq X, Bastian BC, Hockemeyer D. Mutations in the promoter of the telomerase gene TERT contribute to tumorigenesis by a two-step mechanism. Science 2017;357:1416-20.

52. Bell RJ, Rube HT, Kreig A, Mancini A, Fouse SD, Nagarajan RP, Choi S, Hong C, He D, Pekmezci M, Wiencke JK, Wrensch MR, Chang SM, Walsh KM, Myong S, Song JS, Costello JF. Cancer. The transcription factor GABP selectively binds and activates the mutant TERT promoter in cancer. Science 2015;348:1036-9.

53. Spencer KR, Mehnert JM. Mucosal melanoma: epidemiology, biology and treatment. Cancer Treat Res 2016;167:295-320.

54. Vazquez Vde L, Vicente AL, Carloni A, Berardinelli G, Soares P, Scapulatempo C, Martinho O, Reis RM. Molecular profiling, including TERT promoter mutations, of acral lentiginous melanomas. Melanoma Res 2016;26:93-9.

55. Kim JY, Choi M, Jo SJ, Min HS, Cho KH. Acral lentiginous melanoma: indolent subtype with long radial growth phase. Am J Dermatopathol 2014;36:142-7.

56. Dominiak NR, Wick MR, Smith MT. Mucosal melanomas: site-specific information, comparisons with cutaneous tumors, and differential diagnosis. Semin Diagn Pathol 2016;33:191-7.

57. Furney SJ, Turajlic S, Fenwick K, Lambros MB, MacKay A, Ricken G, Mitsopoulos C, Kozarewa I, Hakas J, Zvelebil M, Lord CJ, Ashworth A, Reis-Filho JS, Herlyn M, Murata H, Marais R. Genomic characterisation of acral melanoma cell lines. Pigment Cell Melanoma Res 2012;25:488-92.

58. Harbour JW, Roberson ED, Anbunathan H, Onken MD, Worley LA, Bowcock AM. Recurrent mutations at codon 625 of the splicing factor SF3B1 in uveal melanoma. Nat Genet 2013:45:133-5.

59. Van Raamsdonk CD, Bezrookove V, Green G, Bauer J, Gaugler L, O’Brien JM, Simpson EM, Barsh GS, Bastian BC. Frequent somatic mutations of GNAQ in uveal melanoma and blue naevi. Nature 2009;457:599-602.

60. Carvajal RD, Antonescu CR, Wolchok JD, Chapman PB, Roman RA, Teitcher J, Panageas KS, Busam KJ, Chmielowski B, Lutzky J, Pavlick AC, Fusco A, Cane L, Takebe N, Vemula S, Bouvier N, Bastian BC, Schwartz GK. KIT as a therapeutic target in metastatic melanoma. JAMA 2011;305:2327-34.

61. Smalley KS, Lioni M, Dalla Palma M, Xiao M, Desai B, Egyhazi S, Hansson J, Wu H, King AJ, Van Belle P, Elder DE, Flaherty KT, Herlyn M, Nathanson KL. Increased cyclin D1 expression can mediate BRAF inhibitor resistance in BRAF V600E-mutated melanomas. Mol Cancer Ther 2008;7:2876-83.

62. Krantz BA, Dave N, Komatsubara KM, Marr BP, Carvajal RD. Uveal melanoma: epidemiology, etiology, and treatment of primary disease. Clin Ophthalmol 2017;11:279-89.

63. Jovanovic P, Mihajlovic M, Djordjevic-Jocic J, Vlajkovic S, Cekic S, Stefanovic V. Ocular melanoma: an overview of the current status. Int J Clin Exp Pathol 2013;6:1230-44.

64. Singh AD, Turell ME, Topham AK. Uveal melanoma: trends in incidence, treatment, and survival. Ophthalmology 2011;118:1881-5.

65. Chen X, Wu Q, Depeille P, Chen P, Thornton S, Kalirai H, Coupland SE, Roose JP, Bastian BC. RasGRP3 mediates MAPK pathway activation in GNAQ mutant uveal melanoma. Cancer Cell 2017;31:685-96.

66. Helgadottir H, Höiom V. The genetics of uveal melanoma: current insights. Appl Clin Genet 2016;9:147-55.

67. Van Raamsdonk CD, Griewank KG, Crosby MB, Garrido MC, Vemula S, Wiesner T, Obenauf AC, Wackernagel W, Green G, Bouvier N, Sozen MM, Baimukanova G, Roy R, Heguy A, Dolgalev I, Khanin R, Busam K, Speicher MR, O’Brien J, Bastian BC. Mutations in GNA11 in uveal melanoma. N Engl J Med 2010;363:2191-9.

68. Scheuermann JC, de Ayala Alonso AG, Oktaba K, Ly-Hartig N, McGinty RK, Fraterman S, Wilm M, Muir TW, Müller J. Histone H2A deubiquitinase activity of the Polycomb repressive complex PR-DUB. Nature 2010;465:243-7.

69. Gupta MP, Lane AM, DeAngelis MM, Mayne K, Crabtree M, Gragoudas ES, Kim IK. Clinical characteristics of uveal melanoma in patients with germline BAP1 mutations. JAMA Ophthalmol 2015;133:881-7.

70. Furney SJ, Turajlic S, Stamp G, Thomas JM, Hayes A, Strauss D, Gavrielides M, Xing W, Gore M, Larkin J, Marais R. The mutational burden of acral melanoma revealed by whole-genome sequencing and comparative analysis. Pigment Cell Melanoma Res 2014;27:835-8.

71. Krauthammer M, Kong Y, Ha BH, Evans P, Bacchiocchi A, McCusker JP, Cheng E, Davis MJ, Goh G, Choi M, Ariyan S, Narayan D, Dutton-Regester K, Capatana A, Holman EC, Bosenberg M, Sznol M, Kluger HM, Brash DE, Stern DF, Materin MA, Lo RS, Mane S, Ma S, Kidd KK, Hayward NK, Lifton RP, Schlessinger J, Boggon TJ, Halaban R. Exome sequencing identifies recurrent somatic RAC1 mutations in melanoma. Nat Genet 2012;44:1006-14.

72. Chalmers ZR, Connelly CF, Fabrizio D, Gay L, Ali SM, Ennis R, Schrock A, Campbell B, Shlien A, Chmielecki J, Huang F, He Y, Sun J, Tabori U, Kennedy M, Lieber DS, Roels S, White J, Otto GA, Ross JS, Garraway L, Miller VA, Stephens PJ, Frampton GM. Analysis of 100,000 human cancer genomes reveals the landscape of tumor mutational burden. Genome Med 2017;9:34.

73. Gupta S, Artomov M, Goggins W, Daly M, Tsao H. Gender disparity and mutation burden in metastatic melanoma. J Natl Cancer Inst 2015; doi: $10.1093 / \mathrm{jnci} / \mathrm{djv} 221$

74. Snyder A, Makarov V, Merghoub T, Yuan J, Zaretsky JM, Desrichard A, Walsh LA, Postow MA, Wong P, Ho TS, Hollmann TJ, Bruggeman C, Kannan K, Li Y1, Elipenahli C, Liu C, Harbison CT, Wang L, Ribas A, Wolchok JD, Chan TA. Genetic basis for clinical response to CTLA4 blockade in melanoma. N Engl J Med 2014;371:2189-99.

75. Lu YC, Robbins PF. Cancer immunotherapy targeting neoantigens. Semin Immunol 2016;28:22-7.

76. Alexandrov LB, Nik-Zainal S, Wedge DC, Aparicio SA, Behjati S, Biankin AV, Bignell GR, Bolli N, Borg A, Børresen-Dale AL, Boyault S, Burkhardt B, Butler AP, Caldas C, Davies HR, Desmedt C, Eils R, Eyfjörd JE, Foekens JA, Greaves M, Hosoda F, Hutter B, Ilicic 
T, Imbeaud S, Imielinski M, Jäger N, Jones DT, Jones D, Knappskog S, Kool M, Lakhani SR, López-Otín C, Martin S, Munshi NC, Nakamura H, Northcott PA, Pajic M, Papaemmanuil E, Paradiso A, Pearson JV, Puente XS, Raine K, Ramakrishna M, Richardson AL, Richter J, Rosenstiel P, Schlesner M, Schumacher TN, Span PN, Teague JW, Totoki Y, Tutt AN, Valdés-Mas R, van Buuren MM, van 't Veer L, Vincent-Salomon A, Waddell N, Yates LR; Australian Pancreatic Cancer Genome Initiative; ICGC Breast Cancer Consortium; ICGC MMML-Seq Consortium; ICGC PedBrain, Zucman-Rossi J, Futreal PA, McDermott U, Lichter P, Meyerson M, Grimmond SM, Siebert R, Campo E, Shibata T, Pfister SM, Campbell PJ, Stratton MR. Signatures of mutational processes in human cancer. Nature 2013;500:415-21.

77. Alexandrov LB, Stratton MR. Mutational signatures: the patterns of somatic mutations hidden in cancer genomes. Curr Opin Genet Dev 2014;24:52-60.

78. Freeman JL, Perry GH, Feuk L, Redon R, McCarroll SA, Altshuler DM, Aburatani H, Jones KW, Tyler-Smith C, Hurles ME, Carter NP, Scherer SW, Lee C. Copy number variation: new insights in genome diversity. Genome Res 2006;16:949-61.

79. Conrad DF, Pinto D, Redon R, Feuk L, Gokcumen O, Zhang Y, Aerts J, Andrews TD, Barnes C, Campbell P, Fitzgerald T, Hu M, Ihm CH, Kristiansson K, Macarthur DG, Macdonald JR, Onyiah I, Pang AW, Robson S, Stirrups K, Valsesia A, Walter K, Wei J; Wellcome Trust Case Control Consortium, Tyler-Smith C, Carter NP, Lee C, Scherer SW, Hurles ME. Origins and functional impact of copy number variation in the human genome. Nature 2010;464:704-12.

80. Curtin JA, Fridlyand J, Kageshita T, Patel HN, Busam KJ, Kutzner H, Cho KH, Aiba S, Bröcker EB, LeBoit PE, Pinkel D, Bastian BC. Distinct sets of genetic alterations in melanoma. N Engl J Med 2005;353:2135-47.

81. Merkel EA, Gerami P. Malignant melanoma of sun-protected sites: a review of clinical, histological, and molecular features. Lab Invest 2017:97:630-5.

82. Curtin JA, Busam K, Pinkel D, Bastian BC. Somatic activation of KIT in distinct subtypes of melanoma. J Clin Oncol 2006;24:4340-6.

83. Wang Z, Gerstein M, Snyder M. RNA-Seq: a revolutionary tool for transcriptomics. Nat Rev Genet 2009;10:57-63.

84. Jönsson G, Busch C, Knappskog S, Geisler J, Miletic H, Ringnér M, Lillehaug JR, Borg A, Lønning PE. Gene expression profiling-based identification of molecular subtypes in stage IV melanomas with different clinical outcome. Clin Cancer Res 2010;16:3356-67.

85. Harbst K, Staaf J, Lauss M, Karlsson A, Måsbäck A, Johansson I, Bendahl PO, Vallon-Christersson J, Törngren T, Ekedahl H, Geisler J, Höglund M, Ringnér M, Lundgren L, Jirström K, Olsson H, Ingvar C, Borg A, Tsao H, Jönsson G. Molecular profiling reveals low- and high-grade forms of primary melanoma. Clin Cancer Res 2012;18:4026-36.

86. Azimi F, Scolyer RA, Rumcheva P, Moncrieff M, Murali R, McCarthy SW, Saw RP, Thompson JF. Tumor-infiltrating lymphocyte grade is an independent predictor of sentinel lymph node status and survival in patients with cutaneous melanoma. J Clin Oncol 2012;30:2678-83.

87. Onken MD, Worley LA, Ehlers JP, Harbour JW. Gene expression profiling in uveal melanoma reveals two molecular classes and predicts metastatic death. Cancer Res 2004;64:7205-9.

88. Field MG, Harbour JW. Recent developments in prognostic and predictive testing in uveal melanoma. Curr Opin Ophthalmol 2014;25:2349.

89. Harbour JW. A prognostic test to predict the risk of metastasis in uveal melanoma based on a 15-gene expression profile. Methods Mol Biol 2014;1102:427-40.

90. Farberg AS, Glazer AM, White R, Rigel DS. Impact of a 31-gene expression profiling test for cutaneous melanoma on dermatologists' clinical management decisions. J Drugs Dermatol 2017;16:428-31.

91. Ferris LK, Farberg AS, Middlebrook B, Johnson CE, Lassen N, Oelschlager KM, Maetzold DJ, Cook RW, Rigel DS, Gerami P. Identification of high-risk cutaneous melanoma tumors is improved when combining the online American Joint Committee on cancer individualized melanoma patient outcome prediction tool with a 31-gene expression profile-based classification. J Am Acad Dermatol 2017;76:818-25.

92. Hutter C, Zenklusen JC. The cancer genome Atlas: creating lasting value beyond its data. Cell 2018;173:283-5.

93. Bailey MH, Tokheim C, Porta-Pardo E, Sengupta S, Bertrand D, Weerasinghe A, Colaprico A, Wendl MC, Kim J, Reardon B, Ng PK, Jeong KJ, Cao S, Wang Z, Gao J, Gao Q, Wang F, Liu EM, Mularoni L, Rubio-Perez C, Nagarajan N, Cortés-Ciriano I, Zhou DC, Liang WW, Hess JM, Yellapantula VD, Tamborero D, Gonzalez-Perez A, Suphavilai C, Ko JY, Khurana E, Park PJ, Van Allen EM, Liang H; MC3 Working Group; Cancer Genome Atlas Research Network, Lawrence MS, Godzik A, Lopez-Bigas N, Stuart J, Wheeler D, Getz G, Chen K, Lazar AJ, Mills GB, Karchin R, Ding L. Comprehensive characterization of cancer driver genes and mutations. Cell 2018;173:371-85.

94. Hoadley KA, Yau C, Hinoue T, Wolf DM, Lazar AJ, Drill E, Shen R, Taylor AM, Cherniack AD, Thorsson V, Akbani R, Bowlby R, Wong CK, Wiznerowicz M, Sanchez-Vega F, Robertson AG, Schneider BG, Lawrence MS, Noushmehr H, Malta TM; Cancer Genome Atlas Network, Stuart JM, Benz CC, Laird PW. Cell-of-origin patterns dominate the molecular classification of 10,000 tumors from 33 Types of Cancer. Cell 2018;173:291-304.

95. Liu J, Lichtenberg T, Hoadley KA, Poisson LM, Lazar AJ, Cherniack AD, Kovatich AJ, Benz CC, Levine DA, Lee AV, Omberg L, Wolf DM, Shriver CD, Thorsson V; Cancer Genome Atlas Research Network, Hu H. An integrated TCGA pan-cancer clinical data resource to drive high-quality survival outcome analytics. Cell 2018;173:400-16.

96. Chen H, Li C, Peng X, Zhou Z, Weinstein JN; Cancer Genome Atlas Research Network, Liang H. A pan-cancer analysis of enhancer expression in nearly 9000 patient samples. Cell 2018;173:386-99. 